\title{
Education Research: Multiple sclerosis and neuroimmunology fellowship training status in the United States
}

\author{
Ahmed Z. Obeidat, MD, PhD, Yasir N. Jassam, MBChB, MRCP (UK), Le H. Hua, MD, Gary Cutter, MS, PhD, \\ Corey C. Ford, MD, PhD, June Halper, MSN, APN-C, MSCN, Robert P. Lisak, MD, Nancy L. Sicotte, MD, and \\ Erin E. Longbrake, MD, PhD
}

Neurology ${ }^{\circledR} 2020 ; 94: 495-500$. doi:10.1212/WNL.0000000000009096

\author{
Correspondence \\ Dr. Obeidat \\ aobeidat@mcw.edu
}

\begin{abstract}
Objective

To investigate the current status of postgraduate training in neuroimmunology and multiple sclerosis (NI/MS) in the United States.

\section{Methods}

We developed a questionnaire to collect information on fellowship training focus, duration of training, number of fellows, funding application process, rotations, visa sponsorship, and an open-ended question about challenges facing training in NI/MS. We identified target programs and sent the questionnaires electronically to fellowship program directors.
\end{abstract}

\section{Results}

We identified and sent the questionnaire to $69 \mathrm{NI} / \mathrm{MS}$ fellowship programs. We successfully obtained data from 64 programs. Most programs were small, matriculating 1-2 fellows per year, and incorporated both NI and MS training into the curriculum. Most programs were flexible in their duration, typically lasting 1-2 years, and offered opportunities for research during training. Only $56 \%$ reported the ability to sponsor nonimmigrant visas. Most institutions reported having some internal funding, although the availability of these funds varied from year to year. Several program directors identified funding availability and the current absence of national subspecialty certification as major challenges facing NI/MS training.

\section{Conclusion}

Our study is the first to describe the current status of NI/MS training in the United States. We found many similarities across programs. We anticipate that these data will serve as a first step towards developing a standard NI/MS curriculum and help identify areas where shared resources could enhance trainee education despite differences in training environments. We identified funding availability, certification status, and nonimmigrant visa sponsorship as potential barriers to future growth in the field. 


\section{Glossary}

AAN = American Academy of Neurology; $\mathbf{I M G ~ = ~ i n t e r n a t i o n a l ~ m e d i c a l ~ g r a d u a t e ; ~} \mathbf{M S}=$ multiple sclerosis; $\mathbf{N I}=$ neuroimmunology.

The current scope of postgraduate medical training in neuroimmunology (NI) and multiple sclerosis (MS) in the United States is mostly unknown. Over the last decade, more than 9 different immunomodulatory medications were Food and Drug Administration-approved for treating MS, and dozens more are advancing through the therapeutic pipeline. ${ }^{1}$ As these new medications come with specialized monitoring and safety considerations, the need for specialists intimately familiar with each has become clear. ${ }^{1}$ Over the same period, new neuroimmunologic diagnoses have been increasingly recognized, including neuromyelitis optica spectrum disorders, anti-MOG diseases, and numerous unique autoimmune encephalitides including anti-glial fibrillary acid protein and anti-IgLON5. ${ }^{1-4}$ The increasing utilization of biologic drugs for systemic autoimmune conditions and checkpoint inhibitors for cancers has also created a new set of neuroimmunologic illnesses due to medication side effects. ${ }^{5,6}$ The widening diagnostic palette and complexity of treatment options combined with increasing need for multidisciplinary care underscore the need for comprehensive, standardized NI/MS fellowship training.

Because existing programs may vary widely in their curricula and resources, we investigated the current status of NI/MS fellowship training in the United States.

\section{Methods}

We performed a web search to identify current NI/MS training programs in the United States using the terms "neuroimmunology fellowship," "neuroimmunology training," "autoimmune fellowship," "autoimmune training," "multiple sclerosis fellowship," and "multiple sclerosis training." We also sent emails via the American Academy of Neurology (AAN) Synapse listservs for MS and autoimmune neurology, requesting that fellowship directors self-identify. In addition, we utilized partial fellowship directories compiled by the AAN and the Consortium for MS Centers. When no training program was readily identified at major academic centers but was known to exist by the authors, the research team contacted the $\mathrm{NI} / \mathrm{MS}$ faculty at those institutions to confirm the status of NI/ MS training. Through these methods, we identified a comprehensive list of fellowship directors (appendix e-1, links.lww. com/WNL/B53) and developed a questionnaire (appendix e-2, links.lww.com/WNL/B54) to collect information on fellowship focus (MS, NI, or both); training focus (research, clinical, or combined); duration of training; annual number of trainees; funding; timeline for application/acceptance; call responsibilities; required and elective rotations; and the availability of nonimmigrant visa sponsorship for international medical graduates (IMGs). We emailed the survey to each program director and sent individualized reminders to complete it. The current status of postgraduate NI/MS training in the United States was extrapolated using aggregate data.

\section{Data availability}

Qualified investigators may request any data not directly included in this report, including the full questionnaire.

\section{Results}

We identified and sent questionnaires to $69 \mathrm{NI} / \mathrm{MS}$ fellowship programs and obtained data from 64 programs (93\%). The overall program characteristics are presented in table 1. Most matriculate 1-2 fellows annually, incorporate both MS and NI training, are flexible in duration (typically $1-2$ years), and offer opportunities for research. Seven programs enrolled $\geq 3$ fellows annually.

Fellowship funding sources varied. Most institutions reported having some internal funding, although the availability of these funds varied from year to year. Funding was also commonly obtained from nonprofit (e.g., National Multiple Sclerosis Society, AAN) and for-profit entities. External funding sources typically had to be secured by the fellow or institution well before matriculation but after the institution had committed to accepting the fellow.

Most fellowship programs $(\mathrm{n}=38[60 \%])$ reported conducting fellowship interviews about 18 months before matriculation (during postgraduate year 3). Twenty-five programs (40\%) reported interviewing on a rolling basis. Interestingly, 47 programs (75\%; 1 missing) reported that available positions are usually filled more than 1 year before the starting date. Four (6\%) programs reported that fellowship positions often remained unfilled, while the remaining programs (19\%) filled their available positions within a year of start date. Only 35 programs reported the ability to sponsor nonimmigrant visas (56\%; 2 missing).

All programs confirmed that trainees received clinical exposure to the diagnosis and management of classical demyelinating diseases. Other frequently addressed diagnoses included CNS rheumatologic diseases (62/63), neurologic complications of biologic drugs (e.g., tumor necrosis factor- $\alpha$ inhibitors) (60/ 63), vasculitis (59/63), paraneoplastic syndromes (57/63), encephalitis $(52 / 63)$, autoimmune epilepsy $(42 / 63)$, and peripheral NI (22/63).

The core training environment for NI/MS fellowship programs was the outpatient NI/MS clinic. All programs also 
Table 1 Characteristics of neuroimmunology (NI)/ multiple sclerosis (MS) fellowship programs

\begin{tabular}{|c|c|}
\hline Training focus & No. (\%) \\
\hline Combined NI/MS training & $55(87.3)^{a}$ \\
\hline Separate MS and $\mathrm{NI}$ in same institution & $4(6.3)$ \\
\hline MS & $2(3.2)$ \\
\hline NI & $2(3.2)$ \\
\hline \multicolumn{2}{|l|}{ Duration of training } \\
\hline Only 1 year (clinical or mixed in research) & $20(31.3)$ \\
\hline $\begin{array}{l}\text { Flexible duration (1-2 or more years; } \\
\text { clinical or mixed in research }\end{array}$ & $29(45.3)$ \\
\hline At least 2 years (clinical or mixed in research) & $15(23.4)$ \\
\hline \multicolumn{2}{|l|}{ Maximum number of fellows/year } \\
\hline 1 & $38(59.4)$ \\
\hline 2 & $19(29.7)$ \\
\hline$\geq 3$ & 7 (10.9) \\
\hline \multicolumn{2}{|l|}{ Total fellows in program } \\
\hline 1 & $15(23.4)$ \\
\hline 2 & $31(48.4)$ \\
\hline$\geq 3$ & $18(28.2)$ \\
\hline \multicolumn{2}{|l|}{ Guaranteed institutional funding (fellows/year) } \\
\hline 1 & $32(50)$ \\
\hline 2 & $15(23.4)$ \\
\hline None reported & $17(26.6)$ \\
\hline \multicolumn{2}{|l|}{ Timing of interviews ${ }^{a}$} \\
\hline Postgraduate year 3 & $38(60)$ \\
\hline At any time (rolling basis) & $25(40)$ \\
\hline \multicolumn{2}{|l|}{ Call duties } \\
\hline No call duties & $42(65.6)$ \\
\hline Limited hours of phone calls & $16(25)$ \\
\hline Overnight phone call & $4(6.3)$ \\
\hline Phone and in-house call & $2(3.1)$ \\
\hline
\end{tabular}

offered complementary subspecialty rotations (table 2). Elective rotations included public health, clinical trial management, patient-centered medical home, ataxia/movement disorders, behavioral neurology, health system science, relevant neurogenetics, and laboratory medicine.

In response to an open-ended question about challenges facing NI/MS education, program directors identified concerns about funding availability $(\mathrm{n}=32)$ and the current absence of national certification for NI/MS $(n=4)$. Other identified challenges included nonstandard curricula, application/interview timelines, and heterogeneity in practice environments. Fellowship programs (appendix e-1, links.lww.com/WNL/B53) were geographically clustered, with numerous training opportunities in parts of the country, while other geographic regions had few or no training programs (figure).

\section{Discussion}

$\mathrm{NI}$ is one of the fastest-growing neurologic subspecialties, yet in the absence of standardized fellowship training, there is the potential for high variability in the quality of education that trainees receive. Other neurologic specialties previously experienced a similar phenomenon, and over the last 2 decades many have opted to standardize their programs under the governance of a regulating body (table 3 ). Others implemented a match system for recruiting new fellows. As the NI community considers whether to pursue either of these avenues, it was critical to first evaluate the current state of subspecialty education and achieve consensus about core competencies for neuroimmunologists.

Most training programs incorporate a variety of CNS neuroimmune conditions, including non-MS demyelinating diseases, paraneoplastic syndromes, and autoimmune encephalitides, in contrast to some previously held assumptions. ${ }^{8}$ Exposure to peripheral neuroimmunologic conditions and autoimmune movement disorders was less common, likely because these conditions fall under the purview of other neurologic subspecialties. Graduates of NI/MS training programs should therefore be expected to have expertise in diagnosing and managing most CNS neuroimmune conditions. Discrepancies in the size of training institutions' NI/MS programs, available clinical expertise, and patient referral bases may affect trainees' familiarity with rare, non-MS diagnoses. Opportunities exist for collaboration to ensure that all trainees are exposed to the breadth of central neuroimmunologic diagnoses.

The majority of training programs incorporate subspecialty rotations in complementary disciplines (table 2). Such crossdisciplinary exposure is an essential component of comprehensive neuroimmunologic care and allows the NI/MS trainee to become skilled in symptom management, develop a knowledge base about treatment modalities, and make effective referrals. Neuro-ophthalmologic exposure improves fellows' physical examination skills and enhances their ability to diagnose and manage visual concerns. Neuroradiology exposure helps fellows select and interpret relevant imaging studies. Neurorehabilitation rotations allow fellows to develop skill in managing spasticity and to become familiar with ambulatory assistive devices. Training in neuropsychology helps ensure that future NI/MS specialists effectively identify and address mood disturbances, a common phenomenon among patients with neuroimmune diseases. ${ }^{9}$ A third of NI/MS programs also reported incorporating formal teaching in basic immunology into their curricula. This training expands trainees' understanding of the mechanisms of action underlying current 
Table 2 Variety of diseases encountered and additional rotations during training

\begin{tabular}{llll}
\hline Required & Availability, $\mathbf{n}(\%)$ & Elective & Availability, $\mathbf{n}(\%)$ \\
\hline Neuro-ophthalmology & $36(56)$ & Neuro-ophthalmology & 34 (53) \\
\hline Neuroradiology & $31(48)$ & Neuroradiology & $33(52)$ \\
\hline Neurorehabilitation & $26(41)$ & Neurorehabilitation & $36(56)$ \\
\hline Basic immunology & $22(34)$ & Basic immunology & $33(52)$ \\
\hline Neurourology & $20(31)$ & Neurourology & $30(47)$ \\
\hline Statistics & $18(28)$ & Statistics & $30(47)$ \\
\hline Rheumatology & $14(22)$ & Rheumatology & 28 (44) \\
\hline Neuropsychology & $13(20)$ & Neuropsychology & $37(58)$ \\
\hline Infectious disease & $10(16)$ & Infectious disease & 27 (42) \\
\hline Neurophysiology & $2(3)$ & Neurophysiology & 15(23) \\
\hline Neuropathology & $1(1.5)$ & Neuropathology & $31(48)$ \\
\hline Neuro-oncology & $1(1.5)$ & Neuro-oncology & 15(23) \\
\hline
\end{tabular}

Some programs have specific required rotations that are also available as electives.

immunotherapies, provides the necessary foundation for understanding the limitations of current neuroimmunologic testing, and ensures efficient practice in utilizing panels of autoimmune antibodies.

NI/MS fellowships are not formally accredited by a governing body. This may make enrollment challenging for applicants who require nonimmigrant visa support, as only $56 \%$ of programs reported sponsoring nonimmigrant visas. This may discourage some IMGs from pursuing NI/MS as a career choice.
Many program directors identified lack of predictable funding as a major barrier to NI/MS training. About 3-quarters of the programs reported that institutional funding could be obtained for 1 year of clinical training. Fellows desiring additional research opportunities or a longer fellowship were typically required to secure external funding or earn their salary through clinical productivity. Inconsistencies in the application/interview process were also identified as a barrier. Most programs lacked an application deadline and the window during which applications began to be considered varied widely across institutions. Almost all programs filled more

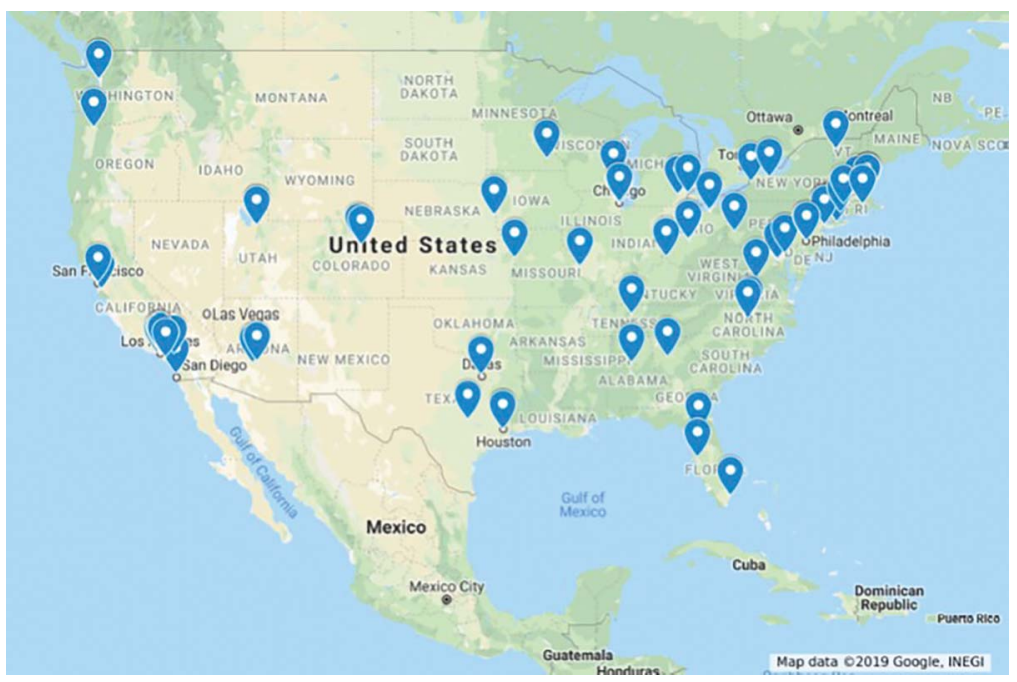


Table 3 Training pathways for neurologic subspecialties

\begin{tabular}{|c|c|c|c|}
\hline Subspecialty & Accreditation & Accreditation date & Match \\
\hline Brain injury medicine & ACGME & 2014 & NRMP \\
\hline Clinical neurophysiology & ACGME & 1992 & No \\
\hline Epilepsy & ACGME & 2011 & No \\
\hline Neuromuscular & ACGME & 2008 & No \\
\hline Pain & ACGME & 2000 & NRMP \\
\hline Sleep & ACGME & 2007 & NRMP \\
\hline Vascular neurology & ACGME & 2005 & NRMP \\
\hline Autonomic disorders & UCNS & 2007 & No \\
\hline Geriatric neurology & UCNS & 2007 & No \\
\hline Neurocritical care & UCNS & 2007 & SF match \\
\hline Behavioral neurology and neuropsychiatry & UCNS & 2004 & No \\
\hline Headache medicine & UCNS & 2005 & No \\
\hline Neuroimaging & UCNS & 2007 & No \\
\hline Clinical neuromuscular pathology & UCNS & 2007 & No \\
\hline Neural repair and rehabilitation & UCNS & 2012 & No \\
\hline Neuro-oncology & UCNS & 2007 & SF match \\
\hline Neuro-ophthalmology & AUPO FCC (optional) & 2005 & No \\
\hline Neuroimmunology & No certifying body & NA & No \\
\hline Movement disorders & No certifying body & NA & SF match \\
\hline Neuroinfectious disease & No certifying body & NA & No \\
\hline
\end{tabular}

Abbreviations: ACGME = American Council for Graduate Medical Education; AUPO FCC = Association of University Professors of Ophthalmology Fellowship Compliance Committee; NRMP = National Resident Matching Program; SF = San Francisco; UCNS = United Council of Neurologic Specialties.

than a year before matriculation. This trend places both applicants and programs under pressure to make decisions before having access to all available options. Several other neurologic subspecialties have implemented a national match system, but this approach may be impractical for NI/MS due to a relatively small number of candidates and a limited number of programs and positions.

This study provides novel data to establish a consensus definition of NI fellowship training. There was widespread agreement that trainees should be exposed to the full spectrum of neuroimmunologic diagnoses and cross-disciplinary rotations during training. These data lay the groundwork for a standard curriculum and identify areas where shared resources could enhance trainees' education despite differences in training environments. Barriers to growth include a nonstandard application/interview timeline, inconsistent nonimmigrant visa sponsorship, and lack of certification status. NI subspecialty training is at a critical juncture, analogous to that faced by neuro-ophthalmology and other neurologic subspecialties in the early 2000s. ${ }^{10}$ There are benefits to clearly defining the subspecialty and identifying a core curriculum for trainees, but there may also be disadvantages associated with a more rigid training environment. Our data will help shape the continuing evolution of this neurologic subspecialty.

\section{Study funding}

No targeted funding reported.

\section{Disclosure}

A.Z. Obeidat reports personal compensation for consulting, speaking, or serving on steering committees for Genzyme, Biogen, Novartis, Alexion Pharmaceuticals, Genentech, and Celgene; fellowship funds from the National Multiple Sclerosis Society (NMSS); research support from the Center for Immunology at the Medical College of Wisconsin; and serving on the editorial board of the International Journal of MS Care. Y.N. Jassam reports serving on an advisory board for Biogen and research support (as PI or coinvestigator; all contracted with University of Kansas) from Novartis, Roche, Alexion, Chugai, MedImmune, Genzyme, Genentech, MedDay, Actelion, Mallinckrodt, TG Therapeutics, and Teva. L.H. Hua reports personal compensation for speaking, consulting, or advisory board activities from Biogen, Genzyme, Novartis, Celgene, 
Genentech, and EMD Serono. G. Cutter reports serving on data and safety monitoring boards of AMO Pharmaceuticals, Biolinerx, Horizon Pharmaceuticals, Hisun Pharmaceuticals, Merck, Merck/Pfizer, Opko Biologics, Neurim, Novartis, Ophazyme, Sanofi-Aventis, Reata Pharmaceuticals, Receptos/Celgene, Teva Pharmaceuticals, NHLBI (Protocol Review Committee), and NICHD (OPRU oversight committee) and serving on consulting or advisory boards for Biogen, Argenix, Brainstorm Cell Therapeutics, Charleston Labs Inc., Click Therapeutics, Genzyme, Genentech, GW Pharma, Klein-Buendel Incorporated, Medimmune, MedDay, Novartis, Roche, Scifluor, Somahlution, Teva Pharmaceuticals, TG Therapeutics, and UT Houston. G. Cutter is employed by the University of Alabama at Birmingham and is President of Pythagoras, Inc., a private consulting company located in Birmingham, Alabama. C. Ford reports personal compensation for consulting or serving on steering committees for Genzyme, Novartis, and Actelion, and for quarterly publication of Science of MS Management, Delaware Medical Group; and received research support (all contracts are with University of New Mexico) from Actelion, Adamas, Alkermes, Biogen, Genentech, Genzyme, Mallinckrodt, MedDay, Novartis, Roche, Sanofi Aventis, Teva, and TG Therapeutics. J. Halper reports no disclosures or conflicts of interest. R.P. Lisak reports serving on the advisory boards of Syntimmune, Novartis, Argenx, and Alexion; served on the Boards of Trustees of the Michigan chapter of the NMSS and the DMC Foundation; serves on the Medical Advisory Board of the GBS/ CIDP Foundation International and the Centers of Excellence and Grants Committee of GBS/CIDP Foundation as well as on the Medical Advisory Board of the Myasthenia Gravis Foundation of America and on its grants committee; and has served as a speaker for patient groups for Teva Pharmaceuticals (nonbranded talks only). R.P. Lisak serves as the Chair of the Health Advisory Committee for the Michigan chapter of NMSS; has received grants from Teva, Novartis, Alexion, Ra Pharmaceuticals, Chugia, Genentech, Medimmune, Argenx, and Catalyst with salary support paid to Wayne State University for his participation in these trials; and has had research support from the NMSS. R.P. Lisak receives honorarium for serving as the Chair of the Adjudication Committee for MedDay for a clinical trial of Biotin in MS and serves on the editorial boards of Clinical Neuropharmacology and Immunology Research. N.L. Sicotte reports funding from the NMSS, PCORI, Biogen, and the Race to Erase MS. E.E. Longbrake reports personal compensation for consulting for Biogen, Celgene, Genentech, Teva, Genzyme, and EMD Serono. Go to Neurology.org/ $\mathrm{N}$ for full disclosures.
Appendix Authors

\begin{tabular}{|c|c|c|}
\hline Name & Location & Contribution \\
\hline $\begin{array}{l}\text { Ahmed Z. } \\
\text { Obeidat, MD, } \\
\text { PhD }\end{array}$ & $\begin{array}{l}\text { Medical } \\
\text { College of } \\
\text { Wisconsin }\end{array}$ & $\begin{array}{l}\text { Designed and conceptualized study, } \\
\text { helped in questionnaire design and } \\
\text { data collection, analyzed the data, } \\
\text { interpreted the data, drafted and } \\
\text { revised the manuscript for } \\
\text { intellectual content }\end{array}$ \\
\hline
\end{tabular}

\begin{tabular}{|c|c|c|}
\hline $\begin{array}{l}\text { Yasir N. Jassam, } \\
\text { MBChB, MRCP } \\
\text { (UK) }\end{array}$ & $\begin{array}{l}\text { University of } \\
\text { Kansas }\end{array}$ & $\begin{array}{l}\text { Designed and conceptualized study, } \\
\text { interpreted the data, revised the } \\
\text { manuscript for intellectual content }\end{array}$ \\
\hline Le H. Hua, MD & $\begin{array}{l}\text { Cleveland } \\
\text { Clinic }\end{array}$ & $\begin{array}{l}\text { Participated in study and } \\
\text { questionnaire design, interpreted } \\
\text { the data, revised the manuscript for } \\
\text { intellectual content }\end{array}$ \\
\hline $\begin{array}{l}\text { Gary Cutter, MS, } \\
\text { PhD }\end{array}$ & $\begin{array}{l}\text { University of } \\
\text { Alabama }\end{array}$ & $\begin{array}{l}\text { Interpreted the data, revised the } \\
\text { manuscript for intellectual content }\end{array}$ \\
\hline $\begin{array}{l}\text { Corey Ford, MD, } \\
\text { PhD }\end{array}$ & $\begin{array}{l}\text { University of } \\
\text { New Mexico }\end{array}$ & $\begin{array}{l}\text { Interpreted the data, revised the } \\
\text { manuscript for intellectual content }\end{array}$ \\
\hline $\begin{array}{l}\text { June Halper, } \\
\text { MSN, APN-C, } \\
\text { MSCN }\end{array}$ & $\begin{array}{l}\text { Consortium } \\
\text { of MS Centers }\end{array}$ & $\begin{array}{l}\text { Interpreted the data, revised the } \\
\text { manuscript for intellectual content }\end{array}$ \\
\hline $\begin{array}{l}\text { Robert P. Lisak, } \\
\text { MD, FRCP (E) }\end{array}$ & $\begin{array}{l}\text { Wayne State } \\
\text { University }\end{array}$ & $\begin{array}{l}\text { Interpreted the data, revised the } \\
\text { manuscript for intellectual content }\end{array}$ \\
\hline $\begin{array}{l}\text { Nancy L. Sicotte, } \\
\text { MD }\end{array}$ & $\begin{array}{l}\text { Cedars-Sinai } \\
\text { Medical } \\
\text { Center }\end{array}$ & $\begin{array}{l}\text { Conceptualized study, interpreted } \\
\text { the data, revised the manuscript for } \\
\text { intellectual content }\end{array}$ \\
\hline $\begin{array}{l}\text { Erin E. } \\
\text { Longbrake, MD, } \\
\text { PhD }\end{array}$ & $\begin{array}{l}\text { Yale } \\
\text { University }\end{array}$ & $\begin{array}{l}\text { Designed questionnaire, major role } \\
\text { in the acquisition of data, } \\
\text { interpreted the data, revised the } \\
\text { manuscript for intellectual content }\end{array}$ \\
\hline
\end{tabular}

\section{References}

1. Comi G, Radaelli M, Soelberg Sørensen P. Evolving concepts in the treatment of relapsing multiple sclerosis. Lancet 2017;389:1347-1356.

2. Okuda DT. Radiologically isolated syndrome: MR imaging features suggestive of multiple sclerosis prior to first symptom onset. Neuroimaging Clin North America 2017;27:265-275.

3. Heidbreder A, Philipp K. Anti-IgLON 5 disease. Curr Treat Options Neurol 2018;20: 29.

4. Iorio R, Damato V, Evoli A, et al. Clinical and immunological characteristics of the spectrum of GFAP autoimmunity: a case series of 22 patients. J Neurol Neurosurg Psychiatry 2018;89:138-146.

5. Supakornnumporn S, Katirji B. Autoimmune neuromuscular diseases induced by immunomodulating drugs. J Clin Neuromuscul Dis 2018;20:28-34.

6. Kemanetzoglou E, Andreadou E. CNS demyelination with TNF- $\alpha$ blockers. Curr Neurol Neurosci Rep 2017;17:36.

7. Gallien P, Gich J, Sánchez-Dalmau BF, Feneberg W. Multidisciplinary management of multiple sclerosis symptoms. Eur Neurol 2014;72:20-25.

8. López-Chiriboga AS, Clardy SL. Emerging subspecialties in neurology: autoimmune neurology. Neurology 2017;89:e129-e133.

9. Feinstein A, Pavisian B. Multiple sclerosis and suicide. Mult Scler J 2017;23:923-927.

10. Frohman L, Digre KB. Ophthalmic subspecialty fellowship accreditation and ophthalmic subspecialty certification: still hot issues. J Neuroophthalmol 2004; 24:92. 


\section{Neurology}

\section{Education Research: Multiple sclerosis and neuroimmunology fellowship training status in the United States}

Ahmed Z. Obeidat, Yasir N. Jassam, Le H. Hua, et al.

Neurology 2020;94;495-500 Published Online before print February 27, 2020

DOI 10.1212/WNL.0000000000009096

This information is current as of February 27, 2020

Updated Information \& Services

References

Citations

Subspecialty Collections

Permissions \& Licensing

Reprints including high resolution figures, can be found at: http://n.neurology.org/content/94/11/495.full

This article cites 10 articles, 2 of which you can access for free at: http://n.neurology.org/content/94/11/495.full\#ref-list-1

This article has been cited by 2 HighWire-hosted articles: http://n.neurology.org/content/94/11/495.full\#\#otherarticles

This article, along with others on similar topics, appears in the following collection(s):

All Demyelinating disease (CNS)

http://n.neurology.org/cgi/collection/all_demyelinating_disease_cns All Education

http://n.neurology.org/cgi/collection/all_education

Multiple sclerosis

http://n.neurology.org/cgi/collection/multiple_sclerosis

Other Education

http://n.neurology.org/cgi/collection/other_education

Information about reproducing this article in parts (figures,tables) or in its entirety can be found online at:

http://www.neurology.org/about/about_the_journal\#permissions

Information about ordering reprints can be found online:

http://n.neurology.org/subscribers/advertise

Neurology ${ }^{\circledR}$ is the official journal of the American Academy of Neurology. Published continuously since 1951, it is now a weekly with 48 issues per year. Copyright () 2020 American Academy of Neurology. All rights reserved. Print ISSN: 0028-3878. Online ISSN: 1526-632X.

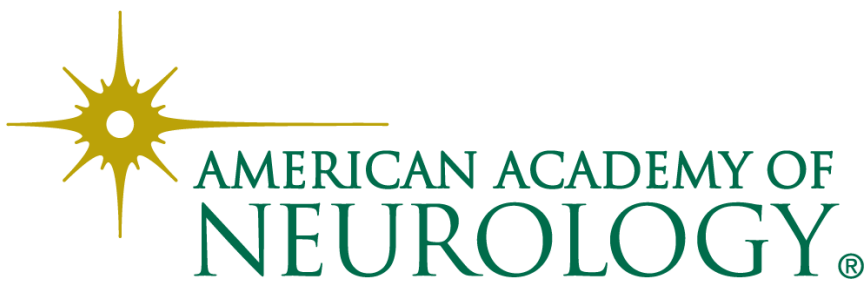

